\title{
XXI. Some electrical properties of flames
}

\section{Magnus Maclean M.A. F.R.S.E. \& Makita Goto}

To cite this article: Magnus Maclean M.A. F.R.S.E. \& Makita Goto (1890) XXI. Some electrical properties of flames, Philosophical Magazine Series 5, 30:183, 188-191, DOI: $10.1080 / 14786449008621375$

To link to this article: http://dx.doi.org/10.1080/14786449008621375

$$
\text { 曲 Published online: } 08 \text { May } 2009 .
$$

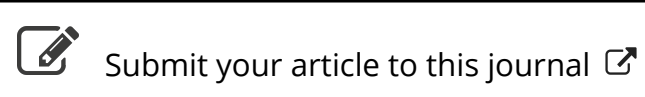

Џلl Article views: 2

Q View related articles $₫$ 
degree of failure of justice which may be expected-amounts to 8 per cent. of the successful; or rather $8 \div \sqrt{2}$, say 6 , per cent., if we define the just verdict as that which would be fornd by taking the average of the results obtained by a variety of competent examiners.

XXI. Some Electrical Properties of Flames. By Magnus MaCLEan, M.A., F.R.S.E., and MaKita Goto (Japan)*.

[Plate V.]

TN connexion with our experiments on the "Electrification of Air by Combustion," we were led to make some experiments on the electricity of different parts of the flame itself. A Bunsen burner was used, and the potentials at different points, both inside and outside of the flame, were examined. In fig. 1, Plate V., is shown the arrangement for examining the inside of the flame. $\mathrm{AA}$ and $\mathrm{BB}$ are platinum wires insulated from the burner and projecting into the flame 5 millim. above the upper end of the burner. These wires can be adjusted by bending so as to lie in various positions from the middle line of the flame to its boundary. In our experiments one of them was left insulated ( $w$ ith its end free in air), while the other was connected to a terminal of a Thomsun Quadrant Electrometer. Or, again, one wire was connected to one terminal of the electrometer, and the other to the other terminal. The Bunsen burner itself was always connected to earth. The sensitiveness of the electrometer was generally such that a difference of potential of $\frac{1}{20}$ volt between the terminals could be observed.

In fig. 2 is shown the arrangement for examining the outside of the flame. $\mathrm{C}$ is a platinum wire fused into a glass tube which covers the wire except a very small portion of its end. $D$ is the scale for measuring the distance of the point of the platinum wire from the boundary of the flame. $E$ is the index.

$\mathrm{By}$ these arrangements it was found that the flame is negatively electrified, while the film of air surronnding the flame is positively electrified. These results were already obtained by Elster and Geitel. Our results agree with what they found, though our method of examining the different parts of the flame is different from their method. (See an abstract of their experiments by S. P. Thompson in 'Nature,'

* Communicated by the Authors. 
Phi.Mag, S, 5. Vol, 30, Pl.V.

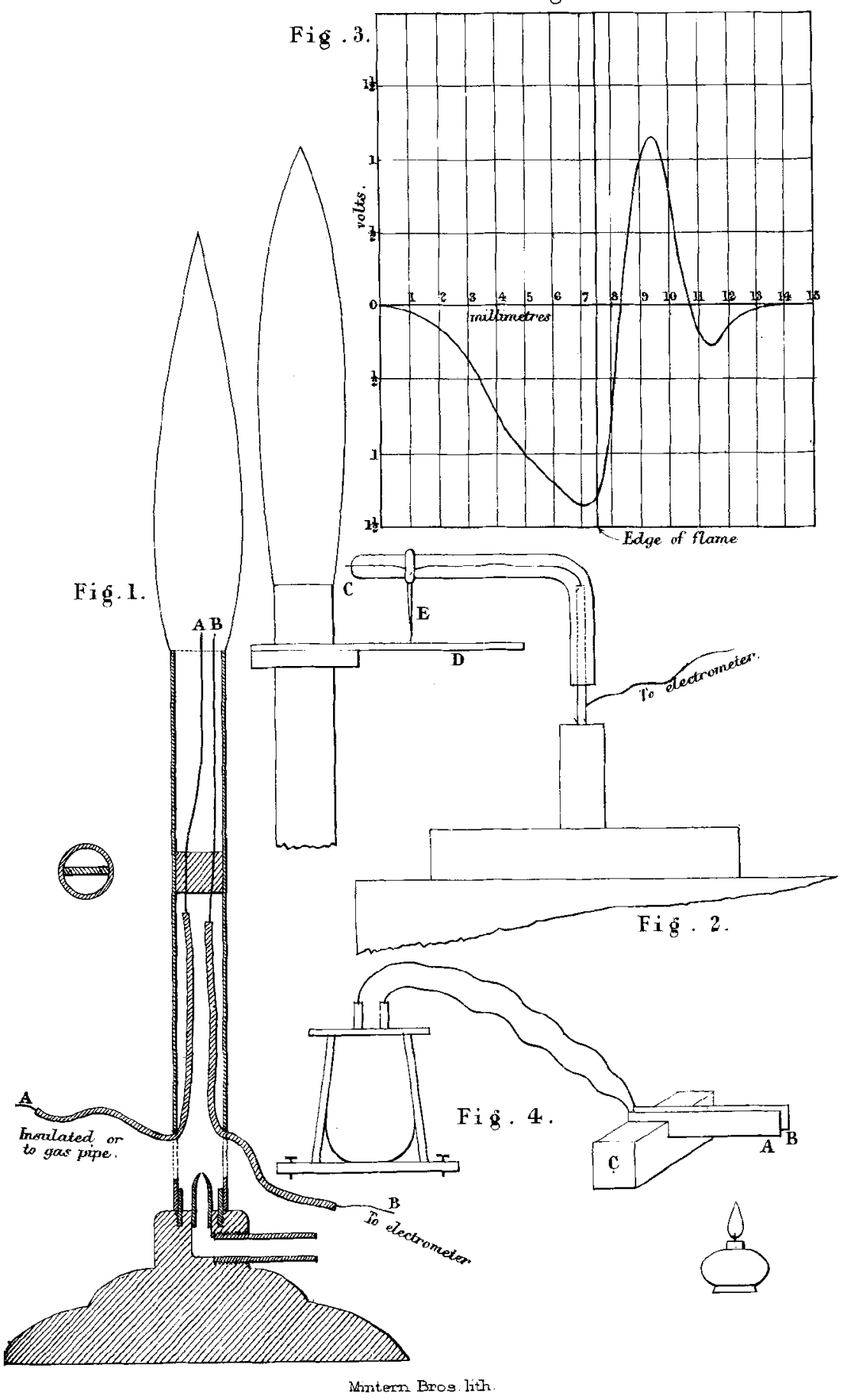


rol. xxvi. No. 666.) In fig. 3 is shown the curve of potential obtained after several observations. It will be observed that the potential at the middle line of the flame is nearly zero, and the surface of maximum negative potential lies just insides of the flame, while the surface of maximum positive potential lies at a distance of 2 millim. from the boundary of the flame. The maximum difference of potential between these two surfaces was found to be between $2 \frac{1}{2}$ and 3 volts.

Similar results were obtained with other flames; but in the case of glowing charcoal the point of the platinum wire had to be brought very close to it in order to obtain the indication of positive potential of the film of air surrounding it.

Having thus made quantitative measurements of the potentials of different parts of a flame, it was expected that the magnitude of the electrification of the air would depend on the part of the flame that was earthed; that is, that maximum positive electrification would be obtained when the most negative part of the flume was earthed and vice vers $\hat{a}$. This expectation was verified by placing the Bunsen burner 3 feet below the nozzle of a water-dropper connected in the ustual manner to a quadrant-electrometer.

The flame of the Bunsen burner was next surrounded by a wire-gauze cage, which was made to lie on the surface of the flame. The burner and wire gauze were connected to a gaspipe for earth. Under this arrangement the effect of the flame was just like that of glowing charcoal, the electrometer connected to the water-dropper showing 6 volts positive.

Another cage open at the top, and connected to earth, was made to lie on the surface of maximum positive potential surrounding the flame. This was difficult to do, and only a part of the cage fulfilled the condition. In this case the air was electrified to $2 \frac{1}{2}$ volts negative, while the burner without the cage electrified the air to less than one volt.

These experiments help to explain why glowing charcoal electrifies air positively, for it acts like a solidified flame connected to earth. For a similar reason spongy platinum, when it glows in hydrogen or coal-gas, is negatively electrified like glowing charcoal.

In these experiments it was desirable to know the maximum electrifying effect of the flame, and this was done by the following method:-The flame to be tested is placed on a stand insulated or uninsulated about 3 feet below the nozzle of the water-dropper, which is connected to the electrometer. The room is electrified, say negatively, to a certain potential which is indicated by the electrometer, by turning 
an electrical machine in the further end of the room. The flame to be tested is then lighted, and the change of deflexion of the electrometer, if any, is noted. If the change of the deflexion is towards negative, the flame is put out and the room is furtber electrified negatively by turning the machine; but if the change of the deflexion is towards positive we wait for some time till the electrification of the room decreases by some scale-divisions, and the flame is again tried to see the effect. This process is continued till no change is observed on lighting the flame. The reading at that time is taken as the maximum effect of the flame. The following observation on a spirit-lamp connected to a gas-pipe may be taken as a specimen :-

\begin{tabular}{|c|c|c|}
\hline $\begin{array}{c}\text { Deflexion before } \\
\text { lighting. }\end{array}$ & $\begin{array}{c}\text { Defiexion after } \\
\text { lighting. }\end{array}$ & $\begin{array}{c}\text { Direction and } \\
\text { mmount of cliange. }\end{array}$ \\
\hline 30 & 20 & +10 \\
15 & 13 & +2 \\
$13 \frac{1}{2}$ & 12 & $+1 \frac{1}{2}$ \\
12 & 11 & +1 \\
6 & $8 \frac{1}{2}$ & $-2 \frac{1}{2}$ \\
$8 \frac{1}{2}$ & $8 \frac{1}{2}$ & 0 \\
\hline
\end{tabular}

The maximum effect is therefore $8 \frac{1}{2}$ divisions, equal to $0 \cdot 6$ volt negative, 14 divisions of the scale corresponding to one volt.

When this same lamp was put on an insulating stand and connected to the negative pole of one Daniell's cell, the other pole being connected to gas-pipe, the maximum deflexion was 40 scale-divisions ( $=3$ volts), and when two Daniell's cells were used in the same way the maximum deflexion was 60 scale-divisions ( $=42 \mathrm{z}$ volts).

Experiments the arrangements for which are shown diagrammatically in fig. 4 , were also tried. A, B are metal plates supported about 2 millim. apart by the insulating material (?, and joined by wires to the terminals of the electrometer. A spirit-lamp is placed about a foot below, so that the hot air from the flame passes between the two metals. Differences of potential produced by this arrangement are given in the following table :- 


\begin{tabular}{|l|l|c|c|}
\hline $\begin{array}{c}\text { Metal positive relative } \\
\text { to other metal. }\end{array}$ & $\begin{array}{c}\text { Metal negative } \\
\text { relative to otber metal. }\end{array}$ & Deflexion. & $\begin{array}{c}\text { Difference of } \\
\text { potential in } \\
\text { rolts. }\end{array}$ \\
\hline Polished Zine B. & Polished Zine A. & $2 \cdot 0$ & 04 \\
Unpolished. & Polished Zinc. & $17 \cdot 0$ & .32 \\
Unpolished Copper. & Polished Copper. & $1 \cdot 6$ & .03 \\
Polished Copper. & Polished Zinc. & $41 \cdot 6$ & .78 \\
Platinum. & Polished Zinc. & $43 \cdot 6$ & .82 \\
Platinum. & Polished Copper. & $9 \cdot 0$ & .17 \\
\hline
\end{tabular}

Hot air from the flame seems to have a different property from ordinary hot air, because the hot air from a large redbot soldering bolt, put in the place of the spirit-lamp, had no effect; nor had breathing upon the plates, nor the vapour from hot water any effect.

\section{Notices respecting New Books.}

The Theory of Determinants in the Historical Order of its Development. - Part 1. Determinants in general, Leibnitz (1693) to Cayley (1841). By Thomas Muir, LL.D. (Macmillan, 1890. Pp. xii +278 .)

DR. MUIR is most favourably known to English mathematicians by bis previous work in the region of Determinants, both in original directions and in the way of gathering together and putting into compendious shape the results obtained by his predecessors. By the way, we are glad to see that a "greatly enlarged" edition of his "treatise" is in course of preparation. It was fitting and natural that he should be inspired to write some such work as the present, if only he could secure the leisure for doing so. He himself remarks that whilst writing his "treatise," "it was repeatedly forced on my attention that the history of the subject bad been very imperfectly looked into. Not only, as it appeared, had injustice been done by the attribution of isolated theorems and demonstrations to authors other than the first discoverers, but the labours of the great founders of the theory bad been disproportionately represented, and a considerable amount of valuable work had actually been lost sight of altogether." He accounts for this naturally enough. The outcome of his discovery was the forming of a resolution " to set about collecting the whole literature of the subject, in order that, as a first step on the way to a history, a biblio- 